\title{
Keadilan Sosial: \\ Telaah atas Filsafat Politik John Rawls
}

\section{Iqbal Hasanuddin}

Universitas Bina Nusantara

iqbalhasanuddin2018@gmail.com

\begin{abstract}
Abstrak: Makalah ini bertujuan untuk menjelaskan Teori Keadilan dalam pandangan John Rawls sebagaimana tertuang di dalam bukunya, $A$ Theory of Justice (1971). Penjelasan dimaksud terkait dengan asumsi-asumsi falsafi yang melatarbelakangi gagasan Rawls tentang keadilan sebagai fairness, yaitu: pandangannya tentang person moral yang rasional, bebas dan setara sebagai titik-tolak bagi filsafat moral dan filsafat politik.
\end{abstract}

Kata-kata Kunci: Rawls, Keadilan, Fairness.

\section{Pendahuluan}

John Rawls (1921-2002) adalah seorang pemikir yang memiliki pengaruh sangat besar di bidang filsafat politik dan filsafat moral. Melalui gagasan-gagasan yang dituangkan di dalam $A$ Theory of Justice (1971), Rawls menjadikan dirinya pijakan utama bagi perdebatan filsafat politik dan filsafat moral kontemporer. Para pemikir setelah Rawls hanya punya dua pilihan: Menyetujui atau tidak menyetujui Rawls. Tidak ada pilihan untuk mengabaikan Rawls sama sekali. Hal ini dikarenakan jangkauan pemikiran Rawls yang sangat luas dan dalam, yakni: Upaya untuk melampaui paham utilitarianisme yang sangat dominan di era sebelum Rawls serta merekonstruksi warisan teori kontrak sosial dari Hobbes, Locke dan Kant sebagai titik tolak untuk merumuskan sebuah teori keadilan yang menyeluruh dan sistematis (Daniels: 1971).

Sebagai ilustrasi atas pengaruh besar Rawls dalam bidang filsafat politik dan filsafat moral tersebut, ada baiknya bila kata-kata dari Robert Nozick, seorang filsuf politik sezaman dan sekaligus kritikus paling utama bagi pikiran-pikiran Rawls, dikemukakan di sini:

A Theory of Justice adalah sebuah karya filsafat politik dan filsafat moral yang kuat, mendalam, subtil, luas, sistematik, yang tidak pernah terlihat lagi semenjak karya-karya John Stuart Mill, atau sebelumnya. Buku ini 
merupakan sumber mata air ide-ide, terintegrasi bersama dalam satu kesatuan yang bagus. Para pemikir filsafat politik sekarang harus bekerja di dalam teori Rawls, atau harus menjelaskan mengapa tidak (Nozick: 1974, h. 183).

Tanggapan-tanggapan atas pemikiran Rawls dalam $A$ Theory of Justice tersebut datang dari berbagai kalangan, terutama dari para pemikir yang berada di barisan libertarian, feminis, pembela utilitarianisme, dan komunitarianisme neo-Aristotelian. Debat antara Rawls dan pendukungnya di satu sisi, serta pengkritiknya dari kalangan komunitarian neo-Aristotelian di lain sisi bahkan kemudian menjadi sangat terkenal sebagai "debat liberalkomunitarian" dalam percaturan filsafat kontemporer. Beberapa di antara filsuf terkenal yang melibatkan diri di dalam perdebatan ini adalah Rawls sendiri, Jurgen Habermas, Charles Taylor, Michael Sandel, dan Michael Walzer (Rasuanto: 2005, h. 26; Magnis-Susseno: 2005, h. 198-216).

Pertanyaannya adalah gagasan apa sebenarnya yang terkandung di dalam $A$ Theory of Justice sehingga buku ini disebut-sebut sebagai salah satu buku yang paling berpengaruh di dalam filsafat politik dan filsafat moral kontemporer? Apa sebenarnya yang dimaksud Rawls dalam bukunya itu sebagai teori keadilan? Argumen-argumen apa yang Rawls pakai untuk mendukung teori keadilannya itu?

Tulisan ini bermaksud menjawab pertanyaan-pertanyaan tersebut. Untuk itu, Pada bagian "Keadilan sebagai Fairness" dijelaskan tujuan utama Rawls merumuskan teori keadilannya. Selanjutnya, pada bagian "Posisi Asali" dijelaskan argumen-argumen Rawls untuk mendukung prinsip-prinsip keadilannya. Bagian "Prinsip-prinsip Keadilan" menjelaskan gagasan substantif Rawls tentang prinsip-prinsip untuk menata masyarakat modern yang tertata secara baik berdasarkan konsepsinya mengenai keadilan sebagai fairness. Kemudian, pada bagian "Tanggapan", saya mencoba membuat refleksi kritis atas gagasan-gagasan Rawls. Tulisan ini diakhiri dengan sebuah catatan penutup yang berisi kesimpulan-kesimpulan.

\section{Keadilan sebagai Fairness}

Apa yang memungkinkan anggota-anggota dari suatu masyarakat secara bersama-sama menerima dan mematuhi ketentuan-ketentuan sosial yang mengatur pembagian hak dan kewajiban di antara mereka? Apa yang bisa mendorong anggota-anggota masyarakat tersebut untuk terlibat secara sukarela dalam berbagai kerja sama sosial? Tentu saja, dalam suatu tatanan sosial yang totaliter, anggota-anggota dari masyarakatnya bisa saja secara terpaksa menerima dan mematuhi ketentuan-ketentuan sosial yang ditetapkan oleh rezim totaliter 
tersebut, karena mereka mungkin merasa takut. Akan tetapi, untuk kedua kalinya dikemukakan di sini, pertanyaannya adalah apa yang memungkinkan munculnya kesukarelaan dari segenap anggota masyarakat untuk menerima dan mematuhi ketentuan-ketentuan sosial yang ada?

Terhadap pertanyaan-pertanyaan ini, Rawls mengemukakan bahwa kesukarelaan segenap anggota masyarakat untuk menerima dan mematuhi ketentuan-ketentuan sosial yang ada hanya dimungkinkan jika masyarakatnya tertata baik di mana keadilan sebagai fariness menjadi dasar bagi prinsip-prinsip pengaturan institusi-institusi yang ada di dalamnya (Rawls: 1971, h. 4-5). Sampai di sini, pertanyaan belum sepenuhnya terjawab. Lantas, apa yang Rawls maksudkan dengan keadilan sebagai fairness? Mengapa fairness itu sedemikian penting dalam rumusan keadilan Rawls? Apa yang memungkinkan suatu keadilan sebagai fairness bisa muncul?

Ketika berbicara tentang ketentutan-ketentuan sosial yang mengatur kehidupan bersama, Rawls sebenarnya sedang menekankan upaya untuk merumuskan prinsip-prinsip yang mengatur distribusi hak dan kewajiban di antara segenap anggota suatu masyarakat. Penekanan terhadap masalah hak dan kewajiban, yang didasarkan pada suatu konsep keadilan bagi suatu kerja sama sosial, menunjukan bahwa teori keadilan Rawls memusatkan perhatian pada bagaimana mendistribusikan hak dan kewajiban secara seimbang di dalam masyarakat sehingga setiap orang berpeluang memperoleh manfaat darinya dan secara nyata, serta menanggung beban yang sama. Karenanya, agar menjamin distribusi hak dan kewajiban yang berimbang tersebut, Rawls juga menekankan pentingnya kesepakatan yang fair di antara semua anggota masyarakat. Hanya kesepakatan fair yang mampu mendorong kerja sama sosial (Rawls: 1971, h. 45).

Demikian, kesepakatan yang fair adalah kunci untuk memahami rumusan keadilan Rawls. Masalahnya, bagaimana kesepakatan yang fair itu bisa diperoleh? Rawls memandang bahwa kesepakatan yang fair hanya bisa dicapai dengan adanya prosedur yang tidak memihak. Hanya dengan suatu prosedur yang tidak memihak, prinsip-prinsip keadilan bisa dianggap fair. Karenanya, bagi Rawls, keadilan sebagai fairness adalah "keadilan prosedural murni" (Ujan: 2001, h. 42). Dalam hal ini, apa yang dibutuhkan oleh mereka yang terlibat dalam proses perumusan konsep keadilan hanyalah suatu prosedur yang fair (tidak memihak) untuk menjamin hasil akhir yang adil pula (Rawls: 1971, h. 4-5). 


\section{Poisisi Asali}

Di atas, Rawls menekankan posisi penting suatu prosedur yang fair demi lahirnya keputusan-keputusan yang oleh setiap orang dapat diterima sebagai hal yang adil. Adapun prosedur yang fair ini hanya bisa terpenuhi apabila terdapat iklim musyawarah yang memungkinkan lahirnya keputusan yang mampu menjamin distribusi yang fair atas hak dan kewajiban. Rawls menegaskan pentingnya semua pihak, yang terlibat dalam proses musyawarah untuk memilih prinsip-prinsip keadilan, berada dalam suatu kondisi awal yang disebutnya "posisi asali" (the original position).

Rawls memunculkan gagasan tentang posisi asali dengan sejumlah catatan: Pertama, adalah penting untuk menegaskan terlebih dahulu bahwa Rawls melihat posisi asali sebagai suatu prasyarat yang niscaya bagi terjaminnya kadilan sebagai fairness. Namun, Rawls tidak pernah memandang posisi asali sebagai suatu yang riil, melainkan merupakan sebuah kondisi awal yang bersifat imajiner. Menurutnya, kondisi awal imajiner ini harus diandaikan dan diterima, karena hanya dengan cara ini tercapainya keadilan sebagai prosedural murni bisa dibayangkan. Hanya saja, kendati bersifat imajiner, bagi Rawls, posisi asali sudah merupakan syarat yang memadai untuk melahirkan sebuah konsep keadilan yang bertujuan pada terjaminnya kepentingan semua pihak secara fair (Rawls: 1971, h. 120).

Kedua, setiap orang yang berpartisipasi di dalam proses perumusan prinsip-prinsip keadilan ini harus benar-benar masuk dalam situasi ideal tersebut. Hanya saja, Rawls percaya bahwa tidak semua orang dapat masuk ke dalam posisi asali. Hanya orang-orang tertentu yang dapat masuk ke dalam situasi hipotesis ini, yakni mereka yang memiliki kemampuan bernalar sesuai dengan standar formal dalam dunia ilmu pengetahuan. Ketentuan-ketentuan ilmiah ini membuka peluang bagi semua orang untuk masuk ke dalam proses musyawarah yang fair (Rawls: 1971, h. 130-135).

Rawls menegaskan bahwa semua pihak yang berada dalam posisi asali harus juga berada dalam keadaan "tanpa pengetahuan." Melalui gagasan tentang "keadaan-tanpa-pengetahuan" tersebut, Rawls ingin menegaskan bahwa semua pihak yang ada dalam posisi asali tidak memiliki pengetahuan mengenai berbagai alternatif yang dapat mempengaruhi mereka dalam proses perumusan dan pemilihan prinsip-prinsip pertama keadilan. Keadaan ketidaktahuan akan hal-hal partikular memang menjadi syarat penting untuk menjamin fairness. Oleh karena itu, semua pihak yang terlibat dalam proses pemilihan tersebut harus mampu melakukan penilaian atas prinsip-prinsip keadilan yang senantiasa 
dipandu oleh pertimbangan-pertimbangan yang umum sifatnya (Rawls: 1971, h. 136-142).

Rawls juga menggambarkan bahwa dalam posisi asali tersebut semua pihak juga diandaikan bersikap saling-tidak-peduli dengan kepentingan pihak lain. Di sini dimaksudkan bahwa semua pihak berusaha dengan sungguhsungguh memperjuangkan apa yang dianggap paling baik bagi dirinya. Pada saat yang sama, mereka juga dianggap tidak saling mengetahui apa yang dapat diperoleh pihak lain bagi dirinya sendiri. Gambaran ini secara sekilas menunjukan karikatur orang-orang yang justru bertolak belakang dengan semangat kerja sama yang menjadi inti konsep keadilan sebagai fairness. Namun demikian, penggambaran Rawls tentang sikap saling-tidak-peduli di antara orang-orang yang ada dalam posisi asali tersebut sebenarnya lebih sebagai sebuah pengandaian agar semua pihak dalam posisi asali mampu membebaskan diri dari rasa iri terhadap apa yang mungkin didapatkan oleh orang lain. Untuk itu, semua orang harus berkonsentrasi hanya pada apa yang terbaik bagi dirinya sendiri.

Pertanyaan yang muncul adalah: Bagaimana setiap pihak yang berusaha mengejar kepentingannya sendiri (rasional) di dalam posisi asali dan berada dalam keadaan "tanpa-pengetahuan" itu pada akhirnya dapat memilih prinsip-prinsip pertama keadilan yang mampu menjamin kepentingan semua pihak? Menurut Rawls, dalam situasi tersebut, maka orang-orang atau para pihak akan memastikan bahwa prinsip keadilan yang akan dirumuskan bisa menjamin distribusi "nilai-nilai primer" (primary goods) yang fair. Dalam hal ini, "nilai-nilai primer" adalah satu-satunya motivasi yang mendorong dan membimbing semua pihak dalam usahanya memilih prinsip-prinsip pertama keadilan. Dengan nilai-nilai primer, Rawls memaksudkan semua nilai sosial dasar yang pasti diinginkan dan dikejar oleh semua manusia. Artinya, pelbagai manfaat yang dilihat dan dihayati sebagai nilai-nilai sosial yang harus dimiliki oleh seseorang agar layak disebut manusia.

Gagasan Rawls tentang posisi asali tersebut sebenarnya merupakan refleksi dari konsep moral tentang person: setiap manusia diakui dan diperlakukan sebagai person yang rasional, bebas, dan setara (memiliki hak yang sama). Dalam pandangan Rawls, manusia sebagai person moral pada dasarnya memiliki dua kemampuan moral, yakni: 1) kemampuan untuk mengerti dan bertindak berdasarkan rasa keadilan dan dengan itu juga didorong untuk mengusahakan suatu kerja sama sosial; dan 2) kemampuan untuk membentuk, merevisi, dan secara rasional mengusahakan terwujudnya konsep yang baik. Rawls menyebut kedua kemampuan ini sebagai a sense of justice dan a sense of the 
good. Kemampuan-kemampuan moral itu memberikan kemungkinan bagi manusia sebagai person moral untuk bertindak secara rasional dan otonom dalam menetapkan cara-cara dan tujuan-tujuan yang dianggap baik bagi dirinya di satu sisi, serta bertindak berdasarkan prinsip-prinsip keadilan di lain sisi (Rawls: 1987, h. 1-88).

\section{Dua Prinsip Keadilan}

Dalam kondisi awal (posisi asali) sebagaimana dijelaskan di atas, Rawls percaya bahwa semua pihak akan bersikap rasional; dan sebagai person yang rasional, semua pihak akan lebih suka memilih prinsip keadilan yang ditawarkannya daripada prinsip manfaat (utilitarianisme). Prinsip itu adalah:

Semua nilai-nilai sosial—kebebasan dan kesempatan, pendapatan dan kekayaan, dan basis harga diri-harus didistribusikan secara sama. Suatu distribusi yang tidak sama atas nilai-nilai sosial tersebut hanya diperbolehkan apabila hal itu memang menguntungkan orang-orang yang paling tidak beruntung (Rawls: 1971, h. 62).

Bertolak dari prinsip umum di atas, Rawls merumuskan kedua prinsip keadilan sebagai berikut: 1 . Setiap orang harus memiliki hak yang sama atas kebebasan dasar yang paling luas, seluas kebebasan yang sama bagi semua orang; 2. Ketidaksamaan sosial ekonomi harus diatur sedemikian rupa sehingga (a) diharapkan memberi keuntungan bagi bagi orang-oang yang paling tidak beruntung, dan (b) semua posisi dan jabatan terbuka bagi semua orang (Rawls: 1971, h. 60).

Dengan demikian, untuk terjaminnya efektivitas dari kedua prinsip keadilan itu, Rawls menegaskan bahwa keduanya harus diatur dalam suatu tatanan yang disebutnya serial order atau lexical order (Rawls: 1971, h. 63-64). Dengan pengaturan seperti ini, Rawls menegaskan bahwa hak-hak serta kebebasan-kebebasan dasar tidak bisa ditukar dengan keuntungan-keuntungan sosial dan ekonomi. Hal ini berarti bahwa prinsip keadilan kedua hanya bisa mendapat tempat dan diterapkan apabila prinsip keadilan pertama telah terpenuhi. Dengan kata lain, penerapan dan pelaksanaan prinsip keadilan yang kedua tidak boleh bertentangan dengan prinsip keadilan yang pertama. Oleh karena itu, hak-hak dan kebebasan-kebebasan dasar dalam konsep keadilan khusus ini memiliki prioritas utama atas keuntungan-keuntungan sosial dan ekonomi (Rawls: 1971, h. 250).

Bagi Rawls, pembatasan terhadap hak dan kebebasan hanya diperbolehkan sejauh hal itu dilakukan demi melindungi dan mengamankan pelaksanaan kebebasan itu sendiri. Itu berarti, perlu diterima suatu pengaturan 
secara kelembagaan atas praktek-praktek kebebasan agar pelaksanaan kebebasan tidak membahayakan kebebasan yang memang menjadi hak setiap orang (Ujan: 2001, h. 74).

Prinsip keadilan yang kedua menuntut bahwa ketidaksamaan dalam pencapaian nilai-nilai sosial dan ekonomi diperbolehkan apabila tetap membuka peluang bagi pihak lain untuk mendapatkan manfaat dalam hal yang sama. Oleh karena itu, ketidaksamaan dalam perolehan nilai sosial dan ekononomi tidak harus selalu dimengerti sebagai ketidakadilan. Inti dari prinsip keadilan yang kedua justru terletak pada sisi ini.

Bagi Rawls, prinsip "perbedaan" dimaksudkan untuk menjamin berlangsungnya suatu masyarakat yang ideal di mana keterbukaan peluang yang sama (dijamin melalui prinsip kesempatan yang adil) tidak akan menguntungkan sekelompok orang dan pada saat yang sama merugikan kelompok orang lainnya. Oleh karena itu, adanya prinsip "perbedaan" merupakan pengakuan dan sekaligus jaminan atas hak dari kelompok yang lebih beruntung (the better off) untuk menikmati prospek hidup yang lebih baik pula. Akan tetapi, dalam kombinasi dengan prinsip kesempatan yang sama dan adil, prinsip itu juga menegaskan bahwa "kelebihan" berupa prospek yang lebih baik itu hanya dapat dibenarkan apabila membawa dampak berupa peningkatan prospek hidup bagi mereka yang kurang beruntung atau paling tidak beruntung (Rawls: 1971, h. 75).

\section{Keadilan dalam Penataan Institusi-instutusi Politik dan Ekonomi}

Konsepsi keadilan Rawls memperlihatkan dukungan dan pengakuan yang kuat akan hak dan kewajiban manusia, baik dalam bidang politik maupun dalam bidang ekonomi. Secara khusus, konsepsi keadilan tersebut menuntut hak pastisipasi yang sama bagi semua warga masyarakat dalam setiap proses pengambilan keputusan politik dan ekonomi. Dengan demikian, diharapkan bahwa seluruh struktur sosial dasar sungguh-sungguh mampu menjamin kepentingan semua pihak.

Dari sudut politik, konsepsi keadilan Rawls diformulasikan ke dalam tiga sendi utama: (1) hak atas partisipasi politik yang sama; (2) hak warga untuk tidak patuh; dan (3) hak warga untuk menolak berdasarkan hati nurani. Ketiga hal ini menjadi manifestasi kelembagaan dari prinsip keadilan pertama dalam teori kedilan Rawls.

Rawls memandang hak atas partisipasi politik yang sama tersebut bisa terakomodasi dalam sebuah sistem politik yang tidak saja bersifat demokratis, tapi juga konstitusional. Sistem politik demokrasi konstitusional di sini 
dicirikan oleh dua hal utama: pertama, adanya suatu badan perwakilan yang dipilih melalui suatu pemilihan yang fair dan bertanggung jawab kepada pemilihnya, yang berfungsi sebagai badan legislatif untuk merumuskan peraturan-peraturan dan kebijakan-kebijakan sosial; dan kedua, adanya perlindungan konstitusional terhadap kebebasan-kebebasan sipil dan politik, seperti kebebasan berpikir dan berbicara, kebebasan berkumpul dan membentuk organisasi politik (Rawls: 1971, h. 222).

Bagi Rawls, sistem politik demokrasi konstitusional harus memberikan ruang bagi hak untuk tidak patuh (pada Negara), karena hak ini adalah konsekuensi logis dari demokrasi. Rawls memaksudkan hak untuk tidak patuh ini sebagai 'suatu tindakan publik, tanpa kekerasan, berdasarkan suara hati tetapi bersifat politis, bertentangan dengan hukum karena biasanya dilakukan dengan tujuan menghasilkan perubahan hukum atau kebijakan pemerintah' (Rawls: 1971, h. 364). Dalam hal ini, Rawls memandang bahwa ada ruang di mana hukum yang ditetapkan tidak bersifat adil sehingga warga Negara boleh melakukan tindakan politik untuk menentang dan mengubahnya melalui cara-cara yang tidak menggunakan kekerasan.

Jika hak untuk tidak patuh dimaksudkan sebagai tindakan politik untuk memperbaiki hukum yang tidak adil, maka hak untuk menolak berdasarkan hati nurani lebih dimaksudkan sebagai ruang yang diberikan kepada seseorang untuk tidak mematuhi hukum jika hal itu dipandang bertentangan dengan hati nuraninya sendiri. Misalnya, jika terdapat sebuah hukum yang meminta warganya untuk berperang sementara terdapat seorang warga yang memiliki keyakinan bahwa membunuh bertentangan dengan prinsip keadilan yang dipegangnya, maka dia berhak untuk menolak untuk ikut berperang (Rawls: 1971, h. 370-380).

Dari sudut penataan ekonomi, konsepsi keadilan Rawls menuntut suatu basis ekonomi yang fair melalui sistem perpajakan yang proporsional (dan bahkan pajak progresif jika diperlukan) serta sistem menabung yang adil sehingga memungkinkan terwujudnya distribusi yang adil pula atas semua nilai dan sumber daya sosial. Di sini perlu ditegaskan bahwa setiap orang mempunyai hak untuk menikmati nilai-nilai dan sumber daya sosial dalam jumlah yang sama, tetapi juga memiliki kewajiban untuk menciptakan kemungkinan yang membawa kemaslahatan bagi masyarakat secara keseluruhan. Prinsip ini tidak hanya berlaku bagi anggota masyarakat dalam generasi yang sama, tetapi juga bagi generasi yang satu dengan generasi yang lainnya. Bagi Rawls, kekayaan dan kelebihan-kelebihan bakat alamiah seseorang 
harus digunakan untuk meningkatkan prospek orang-orang yang paling tidak beruntung di dalam masyarakat (Rawls: 1971, h. 260-285).

\section{Tanggapan Kritis}

Dari gagasan-gagasan yang dikemukakan oleh Rawls tentang teori keadilan, saya menemukan setidak-tidaknya empat hal yang perlu ditanggapi secara kritis; 1) pandangan Rawls tentang subjek sebagaimana direfleksikan dalam konsepsi orang-orang yang ada dalam posisi asali; 2) metode Rawls dalam merumuskan prinsip-prinsip keadilan yang cenderung terjebak dalam monologi di mana prinsip keadilan bisa dikonstruksi secara rasional oleh seorang atau sekelompok orang ahli sembari mengabaikan ruang-ruang dialogis yang bersifat deliberatif; 3) pandangan Rawls tentang perbedaan sosio-ekonomi yang diperbolehkan sejauh menguntungkan kelompok yang paling tidak beruntung; dan 4) peluang untuk menerapkan pajak progresif dalam teori keadilan Rawls telah menjadikan kelompok yang beruntung di dalam masyarakat sebagai alat untuk kepentingan orang-orang yang tidak beruntung.

Pertama, pandangan Rawls tentang subjek sebagaimana direfleksikan dalam konsepsi orang-orang yang ada dalam posisi asali. Melalui konsep posisi asali di mana para pihak yang terlibat berada di dalamnya berada di balik cadar ketidaktahuan, Rawls telah mengabikan posisi penting kondisi-kondisi kemanusiaan aktual dalam merumuskan konsep keadilannya. Teori keadilan Rawlsian dibangun di atas konsep person moral yang mengabaikan identitasidentitas konkret yang ada dalam kehidupan nyata. Padahal, persoalan kerja sama sosial tidak saja terkait dengan masalah-masalah kepentingan manusiawi yang bersifat universal, tapi juga konstalasi-konstalasi partikular terkait identitas yang bersifat spesifik.

Dalam hal ini, teori keadilan Rawls semata-mata menyoroti masalahmasalah "politik redistribusi", yakni bagaimana mendistribusikan hak dan kewajiban secara seimbang, tapi di saat yang sama teori keadilan tersebut mengabaikan masalah-masalah "politik rekognisi", yakni bagaimana menata relasi-relasi sosio-kultural berbasis identitas. Ketika Rawls berbicara tentang struktur dasar masyarakat sebagai basis bagi teori keadilannya, apakah hal itu berarti Negara atau apa? Jika itu adalah Negara, maka apakah di dalamnya dimungkinkan pembicaraan tentang Negara multi-bangsa atau Negara polietnis sebagaimana diwacanakan oleh kalangan multikulturalis?

Kedua, metode Rawls dalam merumuskan prinsip-prinsip keadilan yang cenderung terjebak dalam monologi di mana prinsip keadilan bisa dikonstruksi secara rasional oleh seorang atau sekelompok orang ahli sembari 
mengabaikan ruang-ruang dialogis yang bersifat deliberatif. Metode yang dirumuskan oleh Rawls ini tidak memberikan jalan bagi munculnya konsensus aktual yang dihasilkan dalam percakapan-percakapan sosial yang bebas dominasi. Padahal, dalam situasi konkret, kerja sama sosial seringkali terkendala oleh hambatan-hambatan struktural dan kultural yang bersifat dominatif sehingga tidak ada ruang bagi terciptanya konsensus tentang bagaimana kebijakan publik sejatinya dirumuskan.

Ketiga, pandangan Rawls tentang perbedaan sosio-ekonomi yang diperbolehkan sejauh menguntungkan kelompok yang paling tidak beruntung. Dalam hal ini, Rawls tidak memberikan batasan-batasan tentang perbedaan yang ditoleransi. Jika batasannya semata-mata "sejauh menguntungkan kelompok yang paling tidak beruntung”, maka hal itu menjadi sangat relatif. Selain itu, Rawls juga tidak bicara tentang siapa itu kelompok yang paling tidak beruntung; apakah ketidakberuntungan mereka itu diakibatkan oleh sesuatu yang bersifat arbiter atau akibat dari pilihan-pilihan orang-orang yang bersangkutan. Misalnya, jika ada sekelompok orang yang menjadi miskin karena berjudi, apakah mereka juga berhak untuk dapat bagian dalam proses redistribusi nikmat-nikmat sosial?

Keempat, peluang untuk menerapkan pajak progresif dalam teori keadilan Rawls telah menjadikan kelompok yang beruntung di dalam masyarakat sebagai alat untuk kepentingan orang-orang yang tidak beruntung. Padahal, jika kita berbicara tentang martabat manusia, sejatinya tidak diperkenankan ada manusia yang diposisikan sebagai alat. Sebab, penghargaan atas martabat manusia diandaikan agar kita senantiasa menjadikan seluruh manusia sebagai tujuan pada dirinya, dan tidak pernah menjadikan alat untuk kepentingan-kepentingan di luar dirinya.

\section{Penutup}

Kesimpulan-kesimpulan yang dapat diambil dari pembahasan tentang teori keadilan Rawls ini adalah sebagai berikut.

Pertama, Rawls mengemukakan bahwa kesukarelaan segenap anggota masyarakat untuk menerima dan mematuhi ketentuan-ketentuan sosial yang ada hanya dimungkinkan jika masyarakatnya tertata baik di mana keadilan sebagai fariness menjadi dasar bagi prinsip-prinsip pengaturan institusi-institusi yang ada di dalamnya. Titik-tolak Rawls dalam merancang teori keadilannya adalah konsepsinya tentang person moral yang pada dasarnya memiliki dua kemampuan moral, yakni: 1) kemampuan untuk mengerti dan bertindak berdasarkan rasa keadilan dan dengan itu juga didorong untuk mengusahakan 
suatu kerja sama sosial; dan 2) kemampuan untuk membentuk, merevisi, dan secara rasional mengusahakan terwujudnya konsep yang baik. Rawls menyebut kedua kemampuan ini sebagai a sense of justice dan a sense of the good.

Kedua, Rawls memandang bahwa kesepakatan yang fair hanya bisa dicapai dengan adanya prosedur yang tidak memihak. Hanya dengan suatu prosedur yang tidak memihak, prinsip-prinsip keadilan bisa dianggap fair. Karenanya, bagi Rawls, keadilan sebagai fairness adalah "keadilan prosedural murni”. Dalam hal ini, apa yang dibutuhkan oleh mereka yang terlibat dalam proses perumusan konsep keadilan hanyalah suatu prosedur yang fair (tidak memihak) untuk menjamin hasil akhir yang adil pula.

Ketiga, Rawls menekankan posisi penting suatu prosedur yang fair demi lahirnya keputusan-keputusan yang oleh setiap orang dapat diterima sebagai hal yang adil. Adapun prosedur yang fair ini hanya bisa terpenuhi apabila terdapat iklim kontrak yang memungkinkan lahirnya keputusan dengan kemampuan menjamin distribusi yang fair atas hak dan kewajiban. Rawls menegaskan pentingnya semua pihak, yang terlibat dalam proses pemilihan prinsip-prinsip keadilan, berada dalam suatu kondisi awal yang disebutnya "posisi asali" (the original position). Di sini, posisi asali merupakan suatu tuntutan agar keadilan dalam arti fairness bisa didapatkan. Posisi asali ini juga berfungsi sebagai penghubung antara konsep person moral di satu pihak, dengan prinsip-prinsip keadilan di lain pihak.

Keempat, Rawls yakin bahwa person-person moral yang melakukan musyawarah dalam posisi asali pasti akan memilih prinsip-prinsip keadilan yang dirumuskannya sebagai berikut: 1 . Setiap orang harus memiliki hak yang sama atas kebebasan dasar yang paling luas, seluas kebebasan yang sama bagi semua orang; 2. Ketidaksamaan sosial ekonomi harus diatur sedemikian rupa sehingga (a) diharapkan member keuntungan bagi setiap orang, dan (b) semua posisi dan jabatan terbuka bagi semua orang.

Namun demikian, dari gagasan-gagasan yang dikemukakan oleh Rawls tentang teori keadilan, setidak-tidaknya terdapat empat hal yang perlu ditanggapi secara kritis; 1) pandangan Rawls tentang subjek yang bersifat abstrak dan atomistik; 2) metode Rawls dalam merumuskan prinsip-prinsip keadilan yang cenderung terjebak dalam monologi di mana prinsip keadilan bisa dikonstruksi secara rasional oleh seorang atau sekelompok orang ahli sembari mengabaikan ruang-ruang dialogis yang bersifat deliberatif; 3) pandangan Rawls tentang perbedaan sosio-ekonomi yang diperbolehkan sejauh menguntungkan kelompok yang paling tidak beruntung; dan 4), peluang untuk menerapkan pajak progresif dalam teori keadilan Rawls telah menjadikan 
kelompok yang beruntung di dalam masyarakat sebagai alat untuk kepentingan orang-orang yang tidak beruntung.

\section{Daftar Pustaka}

1. Daniels, Norman, (Ed.), Reading Rawls: Critical Studies on Rawls' A Theory of Justice (Oxford: Basil Blackwell, 1975).

2. Magnis-Susseno, Franz, "Moralitas dan Nilai-nilai Komunitas: Debat Komunitarisme dan Universalisme Etis" dalam Franz MagnisSusseno, Pijar-pijar Filsafat: Dari Gatholoco ke Filsafat Perempuan, dari Adam Muller ke Postmodernisme (Yogyakarta: Penerbit Kanisius, 2005).

3. Nozick, Robert, Anarchy, State, and Utopia (Oxford: Blackwell, 1974).

4. Rawls, John, A Theory of Justice (London: Oxford University Press, 1971).

5. Rawls, John, "Basic Liberties and Their Priority" dalam M. McMurrin (ed.), Liberty, Equality, and Law (Cambrige: Cambridge University Press, 1987).

6. Rasuanto, Bur, Keadilan Sosial: Pandangan Deontologis Rawls dan Habermas; Dua Teori Filsafat Politik Modern (Jakarta: PT Gramedia Pustaka Utama, 2005).

7. Ujan, Andre Ata, Keadilan dan Demokrasi: Telaah Filsafat Politik John Rawls (Yogyakarta: Kanisius, 2001). 